\title{
Detection of Anovulation by Heatmount Detectors and Transrectal Ultrasonography Before Treatment with Progesterone in a Timed Insemination Protocol ${ }^{1}$
}

\author{
J. S. Stevenson, ${ }^{\star 2}$ D. E. Tenhouse, ${ }^{\star}$ R. L. Krisher,† G. C. Lamb, J. E. Larson,§ C. R. Dahlen,\# \\ J. R. Pursley, $\|$ N. M. Bello, $\|$ P. M. Fricke,ף M. C. Wiltbank,ף D. J. Brusveen,ף M. Burkhart, ${ }^{\star \star}$ \\ R. S. Youngquist, ${ }^{\star \star}$ and H. A. Garverick ${ }^{\star \star}$ \\ *Department of Animal Sciences and Industry, Kansas State University, Manhattan 66506-0201 \\ †Department of Animal Sciences, Purdue University, West Lafayette, IN 47907-2054 \\ ¥North Florida Research and Education Center, University of Florida, Marianna 32446-7906 \\ §North Central Research and Outreach Center, University of Minnesota, Grand Rapids 55744 \\ \#Northwest Research and Outreach Center, University of Minnesota, Crookston 56716 \\ |Department of Animal Science, Michigan State University, East Lansing 48824 \\ TDepartment of Dairy Science, University of Wisconsin, Madison 53706 \\ ${ }^{\star \star}$ Department of Animal Science, University of Missouri, Columbia 65211
}

\begin{abstract}
Our objective was to determine the accuracy of identifying noncycling lactating dairy cows before the application of a timed artificial insemination (AI) protocol [with or without progesterone supplementation via a controlled internal drug-release (CIDR) insert and 2 different timings of $\mathrm{AI}$ ] by using heatmount detectors and a single ovarian ultrasound examination. At 6 locations in the Midwest, 1,072 cows were enrolled in a Presynch protocol (2 injections of $\mathrm{PGF}_{2 \alpha} 14 \mathrm{~d}$ apart), with the second injection administered $14 \mathrm{~d}$ before initiating the Ovsynch protocol (injection of GnRH $7 \mathrm{~d}$ before and 48 $\mathrm{h}$ after $\mathrm{PGF}_{2 \alpha}$ injection, with timed $\mathrm{AI}$ at 0 or $24 \mathrm{~h}$ after the second GnRH injection). Heatmount detectors were applied to cows just before the first Presynch injection, assessed $14 \mathrm{~d}$ later at the second Presynch injection (replaced when activated or missing), and reassessed at initiation of the Ovsynch protocol. Ovaries were examined for the presence of a corpus luteum (CL) by ultrasound before the initiation of treatment. Treatments were assigned to cows based on the presence or absence of a CL detected by ultrasound: 1) no CL + no CIDR; 2) no CL + CIDR insert for $7 \mathrm{~d}$; and 3) CL present. Further, alternate cows within the 3 treatments were assigned to be inseminated concurrent with the second GnRH injection of Ovsynch $(0 \mathrm{~h})$ or $24 \mathrm{~h}$ later. Pregnancy was diagnosed at 33 and $61 \mathrm{~d}$ after the second

Received November 12, 2007.

Accepted March 14, 2008.

${ }^{1}$ This project was funded partly by the NC-1006 Regional Research Project of the USDA Cooperative State Research, Extension, and Education Service. Contribution no. 08-91-J from the Kansas Agricultural Experiment Station, Manhattan.

${ }^{2}$ Corresponding author: jss@k-state.edu
\end{abstract}

GnRH injection. By using low $(<1 \mathrm{ng} / \mathrm{mL})$ concentrations of progesterone in serum as the standard for noncycling status, heatmount detectors were activated on a large percentage of noncycling cows ( $>60 \%)$, whereas the single ultrasound examination incorrectly classified noncycling cows only $21 \%$ of the time. Conversely, cycling cows (progesterone $\geq 1 \mathrm{ng} / \mathrm{mL}$ ) were correctly identified 70 to $78 \%$ of the time by heatmount detectors, but 85 to $92 \%$ were correctly identified by ultrasound. Overall accuracy of heatmount detectors and ultrasound was 71 and $84 \%$, respectively. Application of progesterone to cows without a CL at the time of the first injection of $\mathrm{GnRH}$ reduced the incidence of ovulation but increased the proportions of pregnancies per AI at d 33 or 61 compared with nontreated cows without a CL at the onset of the Ovsynch protocol. Percentages of cows pregnant and pregnancy survival did not differ for cows having a CL before treatment compared with those not having a CL and treated with progesterone. Compared with no response, when a follicle ovulated in response to the first GnRH injection, percentage of cows becoming pregnant after the timed AI increased from 33.3 to $41.6 \%$. Timing of AI at 0 or $24 \mathrm{~h}$ after the second GnRH injection did not alter pregnancies per AI, but cows having luteal activity before treatment had improved pregnancies per AI compared with noncycling cows. We conclude that identifying noncycling cows by ultrasound was more accurate than by heatmount detectors. Subsequent progesterone treatment of previously cycling cows not having a CL at the onset of Ovsynch increased the proportion of pregnant cows, equal to that of cows having a CL but not treated with progesterone.

Key words: anovulation, controlled internal drug release, Ovsynch, pregnancy per artificial insemination 


\section{INTRODUCTION}

Reproductive efficiency has fundamental economic importance for dairy operations. Nevertheless, reproductive efficiency of lactating dairy cows is less than optimal, with more than a 50\% decline in pregnancies per AI (P/AI) since 1970 (Butler and Smith, 1989; Washburn et al., 2002). Adequate circulating progesterone concentrations are critical for the normal estrous cycle and for maintenance of pregnancy. In addition, circulating progesterone concentrations before $\mathrm{AI}$ seem to be important for optimal fertility, as demonstrated by a positive correlation between serum progesterone before $\mathrm{AI}$ and subsequent conception rates (Fonseca et al., 1983; Folman et al., 1990). Circulating progesterone concentrations are determined by the balance between rates of progesterone production, primarily by the corpus luteum (CL), and rates of progesterone clearance or metabolism. Lactating dairy cows have much lower circulating progesterone concentrations than would be expected from the size of the CL (Sartori et al., 2002, 2004; Wolfenson et al., 2004). Increased DMI and milk yield seem to increase progesterone metabolism, producing reduced circulating progesterone concentrations in lactating dairy cows (Sangsritavong et al., 2002; Wiltbank et al., 2006). Thus, reducing progesterone metabolism or supplementation of progesterone during reproductive management protocols holds promise for improving dairy cattle fertility.

Previous studies produced inconsistent results after supplementing progesterone via a progesterone-releasing intravaginal controlled internal drug-release (CIDR) insert during various timed AI (TAI) protocols. For example, our previous regional research project reported numerically greater P/AI measured $28 \mathrm{~d}$ after TAI for cows treated with progesterone during the Ovsynch protocol (injection of $\mathrm{GnRH} 7 \mathrm{~d}$ before and $48 \mathrm{~h}$ after $\mathrm{PGF}_{2 \alpha}$ injection, with TAI between 0 and $24 \mathrm{~h}$ after the second GnRH injection; Stevenson et al., 2006). In that study, P/AI were greater for both cycling and noncycling cows treated with the CIDR insert compared with no CIDR treatment, but only at 4 of the 6 locations at $28 \mathrm{~d}$ and at 3 of 6 locations at $56 \mathrm{~d}$ after TAI. This inconsistent response is corroborated by other largescale studies (El-Zarkouny et al., 2004; Galvão et al., 2004; Moreira et al., 2004a,b).

Estrus-detection aids, including tail paint, chalk, and heatmount detectors, are inexpensive tools that may aid in the detection of noncycling cows before first AI. Likewise, examination of ovaries by transrectal palpation (Morrow et al., 1966) or ultrasonography (Silva et al., 2007) is a means of identifying noncycling cows that may benefit from progesterone supplementation as part of a TAI protocol.
Pregnancies per AI are maximized when the TAI of the Ovsynch protocol is administered at $16 \mathrm{~h}$ after the second GnRH injection (Pursley et al., 1998). In practice, this timing is inconvenient and does not correspond to when other management activities occur (e.g., AI, pregnancy diagnosis, vaccinations, and other treatments) while dairy cows are locked up at the feed line after the morning milkings. Further, P/AI was similar when AI occurred concomitant with the second GnRH injection or $24 \mathrm{~h}$ later (Nebel and Jobst, 1998; Pursley et al., 1998).

The objectives of the present experiment were to determine 1) the accuracy of detecting potentially noncycling cows by using heatmount detectors applied to cows for $28 \mathrm{~d}$ before initiating the Ovsynch protocol or by a single ovarian examination using transrectal ultrasonography at the onset of the Ovsynch protocol; 2) the benefit of applying progesterone (via a CIDR insert) during the first $7 \mathrm{~d}$ of the Ovsynch protocol; and 3) P/ AI when timing of AI occurred concurrent with the second GnRH injection of the Ovsynch protocol or 24 $\mathrm{h}$ later.

\section{MATERIALS AND METHODS}

\section{Experimental Locations}

This study was a collaborative project of North Central Regional Research Project 1006 of the Cooperative States Research, Education, and Extension Service (CSREES). Similar treatments were applied to lactating Holstein cows at 6 locations (Indiana, Kansas, Michigan, Minnesota, Missouri, and Wisconsin) where the co-authors were located. A total of 1,072 cows were enrolled between April 2003 and October 2005. A similar experimental design was used at each location. New cows were enrolled weekly or biweekly into breeding clusters. Various location characteristics are shown in Table 1.

\section{Experimental Protocol}

Sampling, procedures, and design of treatments are illustrated in Figure 1. Cows were enrolled in a Presynch + Ovsynch protocol. Two 25-mg injections of $\mathrm{PGF}_{2 \alpha}$ (5 mL of Lutalyse, Pfizer, New York, NY, or 5 $\mathrm{mL}$ of Prostamate, IVX Animal Health Inc., St. Joseph, MO) were given i.m. $14 \mathrm{~d}$ apart. The Ovsynch protocol was then initiated $14 \mathrm{~d}$ after the second Presynch injection by injecting $\mathrm{GnRH}$. Prostaglandin $\mathrm{F}_{2 \alpha}(25 \mathrm{mg})$ was administered $7 \mathrm{~d}$ later and was followed in $48 \mathrm{~h}$ by a second injection of GnRH. All injections of GnRH (100 $\mu \mathrm{g}$ ) were administered i.m., consisting of $2 \mathrm{~mL}$ of OvaCyst (IVX Animal Health Inc.). 
Table 1. Characteristics of the various locations where the study was conducted

\begin{tabular}{lcccccc}
\hline & \multicolumn{7}{c}{ Location $^{1}$} \\
\cline { 2 - 7 } Item & IN & KS & MI & MN & MO & WI \\
\hline Herd size, n & 801 & 200 & 750 & 839 & 200 & 2,000 \\
Rolling herd milk, kg & 10,756 & 13,154 & 12,340 & 13,606 & 10,500 & 11,400 \\
Milking frequency & $3 \times$ & $2 \times$ & $2 \times$ & $3 \times$ & $2 \times$ & $3 \times$ \\
Feeding system & TMR & TMR & TMR & TMR & TMR & TMR \\
Housing & Free stall & Free stall & Free stall & Free stall & Free stall & Free stall \\
Breeding clusters, n & 8 & 25 & 13 & 12 & 27 & 13 \\
Study period & Apr-May & Nov-Jan & Mar-Jun & Jun-Sep & Dec-May & Aug-Oct \\
Calendar year & 2003 & 2003-2005 & 2004 & 2005 & 2003-2005 & 2005 \\
\hline
\end{tabular}

${ }^{1} \mathrm{IN}=$ Indiana; KS = Kansas; $\mathrm{MI}=$ Michigan; MN = Minnesota; $\mathrm{MO}=$ Missouri; $\mathrm{WI}=$ Wisconsin.

Heatmount detectors (Kamar Inc., Steamboat Springs, CO) were affixed midline to the rump of each cow between the tail head and the tuber coxae (hook bones). Detectors were placed on all cows just before the first Presynch injection and were assessed before the second Presynch and the first GnRH injection of Ovsynch. The condition of the heatmount detector was recorded as red, white, partially red (leaky), or missing. A new detector was applied before each injection when the detector was activated or missing. For purposes of this experiment, sexual behavior associated with estrus was assumed to have occurred when the heatmount detector was activated or missing (ovulatory or cycling cows). Leaky or nonactivated detectors were assumed to be associated with no prior estrual activity (anovulatory or noncycling cows).

\section{Treatments}

At the onset of the Ovsynch protocol, ovaries were examined by transrectal ultrasonography. Ultrasonography was conducted by using a transrectal 5.0- or 7.5$\mathrm{MHz}$ linear-array transducer (Aloka 500V; Corometrics Medical Systems Inc., Wallingford, CT). Follicles and luteal structures were mapped and follicles were sized by using internal calipers. Treatments were assigned to cows based on the presence of a CL (CL absent vs. CL present): 1) noncycling (no CL + no CIDR); 2) noncycling (no CL + CIDR insert for $7 \mathrm{~d}$ ); and 3) cycling (CL present). Further, alternate cows within the 3 treatments were assigned to be inseminated concurrently with the second GnRH injection of Ovsynch $(0 \mathrm{~h})$ or 24 $\mathrm{h}$ later. Pregnancy was diagnosed at 33 and $61 \mathrm{~d}$ after

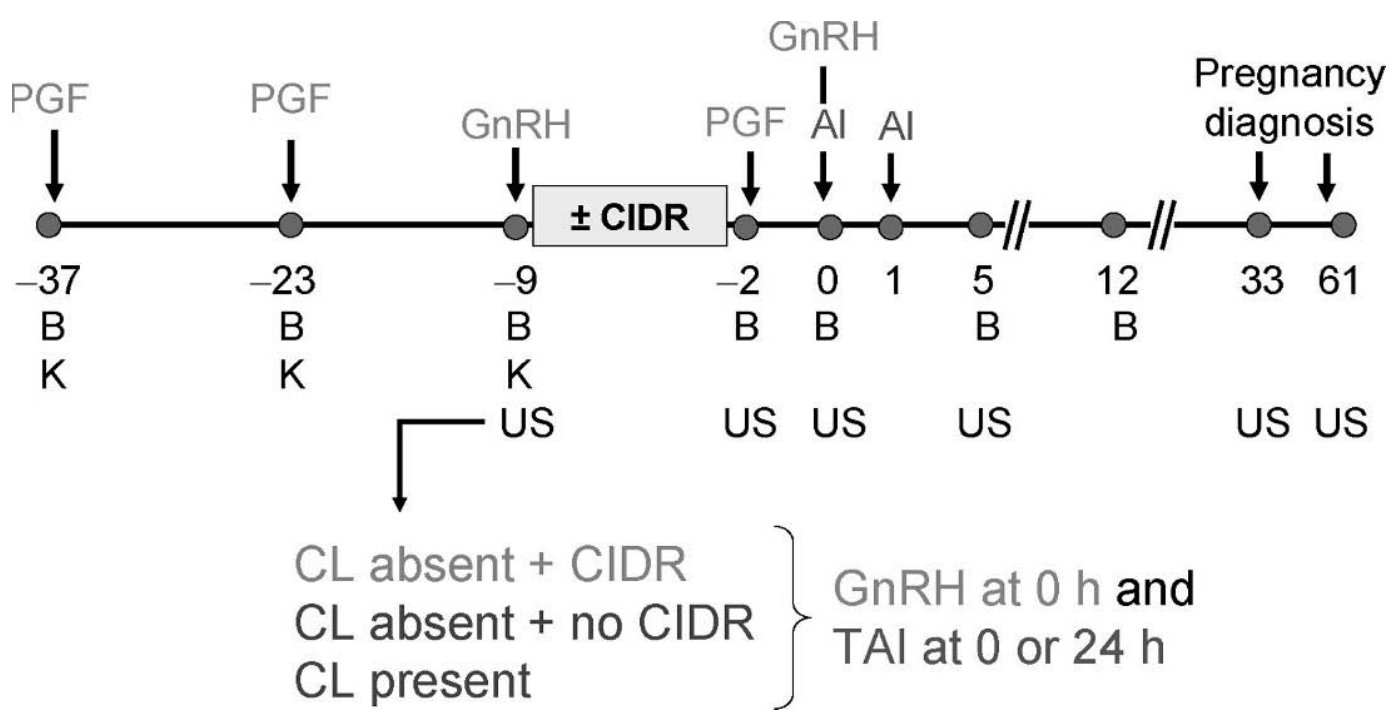

Figure 1. Experimental protocol showing the design of treatments. Heatmount detectors (K) were applied to detect whether a cow was mounted during a specific period. Activated heatmount detectors were replaced at each evaluation. Blood (B) was collected before various injections and twice post-AI. Presence of a corpus luteum (CL) was detected by transrectal ultrasonography (US) and cows without a CL alternately received a progesterone-releasing intravaginal controlled internal drug-release (CIDR) insert. Cows having a CL present received no CIDR insert. All cows received $\mathrm{GnRH}$ at $48 \mathrm{~h}$ after $\mathrm{PGF}_{2 \alpha}(\mathrm{PGF})$ and were inseminated before the second $\mathrm{GnRH}$ injection $(0 \mathrm{~h})$ or $24 \mathrm{~h}$ later within the 3 treatments. Pregnancy was diagnosed at $33 \mathrm{~d}$ after timed AI and was reconfirmed at $61 \mathrm{~d}$ after timed AI. 
the second GnRH injection. The presence of fluid in the uterus, a CL, and a viable embryo were evidence of pregnancy. For cows that were pregnant at the first diagnosis (d 33), a subsequent ultrasound examination at $\mathrm{d} 61$ was used to determine pregnancy loss.

At 3 locations (Kansas, Michigan, and Minnesota), follicles also were mapped and sized at further ovarian exams performed by ultrasound before the $\mathrm{PGF}_{2 \alpha}$ and second GnRH injections of Ovsynch, and at $5 \mathrm{~d}$ after the second GnRH injection to determine whether ovulation had occurred in response to the second GnRH injection. Blood was collected at all locations before each hormonal injection and again at 5 and $12 \mathrm{~d}$ after the second $\mathrm{GnRH}$ injection. Concentrations of progesterone were measured to determine luteal activity before and after treatment.

\section{Progesterone Immunoassays}

Serum concentrations of progesterone for samples collected at 3 locations were quantified by RIA (Skaggs et al., 1986). For Kansas samples, intra- and interassay coefficients of variation were 6.3 and $7.4 \%$, respectively. Repeated pool samples averaged $3.5 \pm 0.1 \mathrm{ng} / \mathrm{mL}$ in 11 assays. For Michigan samples, intra- and interassay coefficients of variation were 4.9 and $5.3 \%$, respectively. Repeated pool samples averaged $4.1 \pm 0.1 \mathrm{ng} / \mathrm{mL}$ in 6 assays. For Minnesota samples, intra- and interassay coefficients of variation were 7.2 and $8.4 \%$, respectively. Repeated pool samples averaged $4.7 \pm 0.1 \mathrm{ng} / \mathrm{mL}$ in 8 assays.

Serum concentrations of progesterone for Missouri samples were quantified by RIA (Progesterone Coat-aCount kit, Diagnostic Products Corp., Los Angeles, CA; Kirby et al., 1997). Intra- and interassay coefficients of variation were 3.0 and $10.2 \%$, respectively.

Serum concentrations of progesterone for samples collected at 2 locations (Indiana and Wisconsin) were quantified by ELISA (Rasmussen et al., 1996), with intra- and interassay coefficients of variation of 4.8 and $8.9 \%$, respectively.

\section{Statistical Analyses}

Ovulation was assumed to have occurred when concentrations of progesterone were $\geq 1 \mathrm{ng} / \mathrm{mL}$ in any or all of the 3 samples collected before the first and second Presynch injection and before the onset of treatment. Assessment of prior luteal activity by examining serum concentrations of progesterone was considered to be the standard with which accuracy of the heatmount detectors and the single ultrasound exam were compared. Our first objective was to determine whether noncycling cows could be detected accurately by heat- mount detectors or by a single ultrasound examination of ovarian structures. Prior ovulatory activity and estrous cycles were assumed to have occurred if the heatmount detector was activated or missing at any or all of the observation times during the 28-d period between the first Presynch injection and the first GnRH injection of Ovsynch. Prior ovulatory activity was assumed to have occurred when a CL was detected by ultrasonography before the onset of the Ovsynch protocol and treatment.

Measures of correct noncycling status, correct luteal activity, false positives, and false negatives were calculated (procedure FREQ; SAS Institute Inc., Cary, NC), in addition to sensitivity, specificity, apparent prevalence, and predictive values positive and negative (Win Episcope 2.0). Kappa values were calculated by using procedure FREQ. Kappa is a measure of repeatability in which a value of 1 indicates perfect agreement and 0 indicates the amount of agreement that occurs by chance alone. A kappa value of 0.4 to 0.5 indicates moderate agreement, 0.5 to 0.6 indicates good agreement, and values $>0.6$ indicate excellent agreement (Martin et al., 1987).

Characteristics and outcomes of various descriptive traits by location were calculated by using a general linear model procedure (procedure GLM; SAS Institute Inc.), with a model consisting of location, lactation number $(1,2$, and $3+)$, and their interaction. Means were separated by using the least significant difference (LSD) in procedure GLM when a protected $F$-test $(P \leq$ 0.05 ) was detected in the ANOVA. Traits summarized for each location included a standard calving difficulty score $(\mathbf{C D S} ; 1=$ no assistance; $2=$ slight problem; 3 = needed assistance; $4=$ considerable force; and $5=$ extreme difficulty); BCS ( $1=$ thin and $5=$ fat $)$ at calving and before the first Presynch injection; DIM at TAI; P/ $\mathrm{AI}$ at $\mathrm{d} 33$ and 61; pregnancy loss during that interval; luteal activity before treatment based on serum concentrations of progesterone; and regression of the CL (cows having elevated concentrations of progesterone 48 to $72 \mathrm{~h}$ before AI, in which blood progesterone was $<1 \mathrm{ng} /$ $\mathrm{mL}$ at $48 \mathrm{~h}$ after the $\mathrm{PGF}_{2 \alpha}$ injection of the Ovsynch protocol) in response to the $\mathrm{PGF}_{2 \alpha}$ of the Ovsynch protocol.

Ovarian characteristics (ovulation incidence in response to first GnRH of Ovsynch), number of CL per cow, proportion of cows having a CL before $\mathrm{PGF}_{2 \alpha}$ of Ovsynch, diameter of the ovulatory follicle before the second GnRH injection, and ovulation incidence after the second GnRH injection were analyzed by procedure GLM by using a model consisting of treatment (no CL + no CIDR, no CL + CIDR, and CL present), lactation number, location, 2-way interactions of treatment and lactation number and location, CDS, and BCS at the 
Table 2. Selected outcomes of lactating dairy cows enrolled at each location

\begin{tabular}{|c|c|c|c|c|c|c|c|}
\hline \multirow[b]{2}{*}{ Item } & \multicolumn{6}{|c|}{ Location } & \multirow[b]{2}{*}{ Mean or total } \\
\hline & IN & $\mathrm{KS}$ & MI & $\mathrm{MN}$ & MO & WI & \\
\hline Cows enrolled, $\mathrm{n}$ & 80 & 217 & 153 & 194 & 242 & 186 & 1,072 \\
\hline Calving difficulty score ${ }^{1}$ & $1.5^{\mathrm{a}}$ & $1.3^{\mathrm{ac}}$ & $1.2^{\mathrm{b}}$ & $1.7^{\mathrm{d}}$ & $1.4^{\mathrm{a}}$ & $1.3^{\mathrm{bc}}$ & $1.3^{* *}$ \\
\hline BCS postcalving ${ }^{1}$ & $2.9^{\mathrm{a}}$ & $2.6^{\mathrm{b}}$ & $2.7^{\mathrm{c}}$ & $3.1^{\mathrm{d}}$ & $2.9^{\mathrm{a}}$ & - & $2.8^{* *}$ \\
\hline BCS at Presynch ${ }^{1,2}$ & 一 & $2.3^{\mathrm{a}}$ & $2.4^{\mathrm{b}}$ & $2.8^{\mathrm{c}}$ & $2.7^{\mathrm{d}}$ & $2.9^{\mathrm{c}}$ & $2.6^{* *}$ \\
\hline Days postpartum at first $\mathrm{AI}^{3}$ & $72^{\mathrm{a}}$ & $79^{\mathrm{b}}$ & $82^{c}$ & $69^{\mathrm{d}}$ & $75^{\mathrm{e}}$ & $72^{\mathrm{a}}$ & $75 * *$ \\
\hline Pregnancies per AI at $33 \mathrm{~d},{ }^{4} \%$ & 37.5 & 42.9 & 36.0 & 29.4 & 33.1 & 36.3 & 35.7 \\
\hline Pregnancies per AI at $61 \mathrm{~d},{ }^{4} \%$ & $37.5^{\mathrm{a}}$ & $37.3^{\mathrm{a}}$ & $33.3^{\mathrm{ab}}$ & $22.7^{\mathrm{b}}$ & $29.8^{\mathrm{ab}}$ & $35.2^{\mathrm{a}}$ & $32.0 *$ \\
\hline Pregnancy loss (33 to $61 \mathrm{~d}$ ), \% & $0.0^{\mathrm{ac}}$ & $12.9^{\mathrm{a}}$ & $7.3^{\mathrm{ac}}$ & $22.8^{\mathrm{b}}$ & $10.0^{\mathrm{ac}}$ & $3.0^{\mathrm{c}}$ & $10.2^{*}$ \\
\hline Luteal activity before treatment, ${ }^{5} \%$ & $92.5^{\mathrm{ab}}$ & $91.2^{\mathrm{a}}$ & $89.5^{\mathrm{a}}$ & $69.1^{\mathrm{c}}$ & $79.3^{\mathrm{bd}}$ & $87.3^{\mathrm{a}}$ & $83.7 * *$ \\
\hline Regression of CL, ${ }^{6} \%$ & $88.4^{\mathrm{ab}}$ & $86.7^{\mathrm{bc}}$ & $87.4^{\mathrm{bc}}$ & $81.9^{b}$ & $94.8^{\mathrm{a}}$ & $90.6^{\mathrm{ac}}$ & $88.5^{* *}$ \\
\hline
\end{tabular}

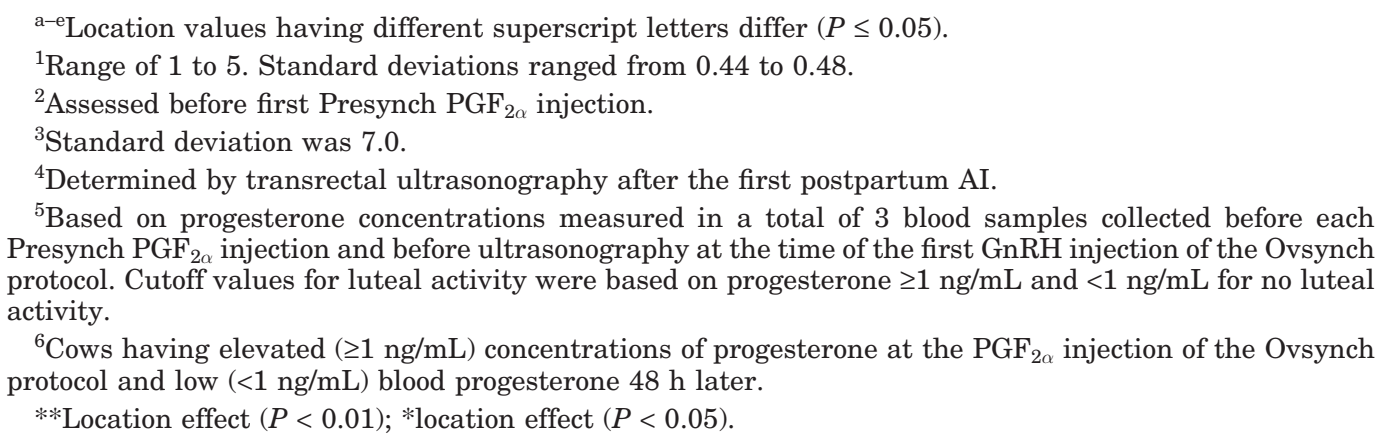

second Presynch injection (covariate). A priori contrasts were constructed to compare treatments (no CL + no CIDR, and no CL + CIDR) vs. cows having a CL present and the effect of absence or presence of a CIDR in cows with no CL.

Pregnancies per AI at $\mathrm{d} 33$ and 61 and pregnancy loss during that interval were analyzed by using a similar model consisting of treatment, lactation number, location, time of AI ( 0 vs. $24 \mathrm{~h}$ ), 2-way interactions of treatment and the preceding variables, location $\times$ time of AI, sire and technician, each nested within location, and CDS. Similar a priori contrasts of treatments were constructed.

Concentrations of progesterone were compared between CIDR and no-CIDR cows for samples collected before the $\mathrm{PGF}_{2 \alpha}$ injection of Ovsynch, the second GnRH injection, and at 5 and $12 \mathrm{~d}$ after the second GnRH injection. The ANOVA consisted of treatment (no CL + no CIDR, no CL + CIDR, and CL present), cycling status based on progesterone concentrations in blood serum before treatments were applied, lactation number, location, all 2-way interactions with treatment, and CDS. For the latter 2 collection times, concentrations assessed from $\mathrm{d} 5$ and 12 after the second GnRH injection, pregnancy status, and its interaction with treatment also were included in the model.

Ancillary models were applied to determine the effects of cycling status, lactation number, location, CDS, and BCS on the number of ovarian follicles $\geq 10 \mathrm{~mm}$ in diameter, diameter of the largest follicle, and propor- tion of cows having a CL before onset of the treatment. In addition, P/AI at d 33 was analyzed according to various progesterone patterns that occurred in blood collected at 3 times before each Presynch and the first $\mathrm{GnRH}$ injection. These samples of high $(\mathrm{H} ; \geq 1 \mathrm{ng} / \mathrm{mL})$ and low (L; <1 ng/mL) concentrations formed 8 permutations of progesterone patterns (e.g., LHH, HHH, HLL, HLH, HHL, LLH, LLL, and LHL) that were included in a model consisting of treatment (no CL + no CIDR, no CL + CIDR, and CL present), time of AI, lactation number, location, progesterone pattern, all 2-way interactions with treatment, incidence of ovulation in response to the first GnRH injection and its interaction with progesterone pattern, CDS, and sire and technician, each nested within location. With the addition of progesterone concentration before the $\mathrm{PGF}_{2 \alpha}$ injection plus the pretreatment cycling status of cows, P/AI at d 33 was compared to determine whether luteal status before or during the Ovsynch protocol was a predictor for the benefit of adding supplemental progesterone via the CIDR insert.

\section{RESULTS AND DISCUSSION}

\section{Location Characteristics}

The various outcomes of lactating dairy cows treated at each of the 6 locations are summarized in Table 2. A total of 1,072 cows were enrolled in the study in 6 states in the Midwest, but for some traits assessed, 
Table 3. Relationship between circulating progesterone concentrations in individual cows at the time of first GnRH injection of Ovsynch and the presence of an activated heatmount detector or an ultrasonically detected corpus luteum (CL) at the same time

\begin{tabular}{lcc}
\hline $\begin{array}{l}\text { Progesterone }(\mathrm{ng} / \mathrm{mL}) \\
\text { at } 1 \text { st } \mathrm{GnRH} \text { injection }\end{array}$ & $\begin{array}{c}\text { Cows with activated } \\
\text { heatmount patches, \% }\end{array}$ & $\begin{array}{c}\text { Cows with ultrasound- } \\
\text { detected CL, \% }\end{array}$ \\
\hline$\leq 0.25$ & $58.3(98 / 168)$ & $15.7(24 / 153)$ \\
0.26 to 0.50 & $69.4(43 / 62)$ & $33.3(21 / 63)$ \\
0.51 to 1.0 & $68.2(45 / 66)$ & $52.6(30 / 57)$ \\
1.01 to 2.0 & $62.5(60 / 96)$ & $75.0(69 / 92)$ \\
2.01 to 3.0 & $65.4(71 / 107)$ & $97.9(87 / 99)$ \\
3.01 to 4.0 & $69.2(117 / 169)$ & $95.5(148 / 155)$ \\
4.01 to 5.0 & $69.3(104 / 150)$ & $97.8(135 / 138)$ \\
5.01 to 6.0 & $67.0(59 / 88)$ & $97.7(128 / 80)$ \\
$>6.0$ & $76.2(109 / 143)$ & $971)$ \\
\hline
\end{tabular}

${ }^{1}$ Activated heatmount patches included those that had been rubbed off and were missing at the first GnRH injection.

data were available for fewer cows. Nearly all traits in Table 2 differed among locations, except for P/AI at d 33. Calving difficulty scores averaged $1.3 \pm 0.48$ (SD) among locations and ranged from 1.2 to 1.7. Average BCS after calving and before the first Presynch injection $(37 \pm 7 \mathrm{DIM})$ were $2.8 \pm 0.48(\mathrm{SD})$ and $2.6 \pm 0.44$ (SD), respectively.

Days in milk at TAI averaged $75 \pm 7$ (SD), with all cows first inseminated between 61 and $107 \mathrm{~d}$ (90\% were inseminated between 61 and 82 DIM). Pregnancies per $\mathrm{AI}$ at d 33 and 61 averaged in the low- to mid-30\% range, with pregnancy loss averaging $10.2 \%$. Cows having luteal activity before treatment (65 \pm 7 DIM), as assessed by concentrations of progesterone in 3 blood samples collected for $28 \mathrm{~d}$ before treatment, averaged 83.7\%. Regression of the CL in response to the $\mathrm{PGF}_{2 \alpha}$ of the Ovsynch protocol averaged $88.5 \%$ across locations.

\section{Detection of Noncycling Cows}

Our first objective was to determine the accuracy of detecting noncycling cows by means of heatmount detectors or a single ultrasound examination of ovarian structures in comparison with serum concentrations of progesterone. At the first Presynch $\mathrm{PGF}_{2 \alpha}$ injection, 45.5\% (485/1,067) of cows had circulating progesterone concentrations $\geq 1 \mathrm{ng} / \mathrm{mL}$. By the time of the second Presynch $\mathrm{PGF}_{2 \alpha}$ injection, however, another $20 \%$ of cows had elevated concentrations of progesterone (694/ $1,067=65 \%$ ). This increased percentage resulted from a total of 282 cows that had low progesterone at the first Presynch injection but then had high progesterone at the second Presynch injection $(282 / 1,067=26.4 \%)$, with only $6.8 \%(73 / 1,067)$ of cows changing from high (first Presynch injection) to low (second Presynch injection). At the time of the first GnRH injection of Ovsynch, a slightly greater percentage of cows were classified as having high progesterone $(768 / 1,067=72 \%)$. A small proportion of cows $(96 / 1,067=9 \%)$ had low progesterone at the first GnRH injection after being high at the second Presynch injection, whereas $15.9 \%(170 / 1,067)$ of cows changed from low (second Presynch injection) to high progesterone (first $\mathrm{GnRH}$ injection of Ovsynch). A small proportion of cows $(126 / 1,067=11.8 \%)$ having low progesterone at both Presynch injections subsequently had high progesterone at the first GnRH injection of Ovsynch (prior noncycling cows that ovulated for 14 d before the start of Ovsynch). Thus, even after both Presynch injections, 28\% (299/1,067) of cows continued to have lower circulating progesterone concentrations at the first GnRH injection of Ovsynch. This is consistent with results from other studies using a Presynch protocol before Ovsynch (El-Zarkouny et al., 2004; Galvão et al., 2004).

To assess the accuracy of the ultrasound and heatmount procedures, we first compared results using only the progesterone concentration at the time of the first GnRH injection of Ovsynch. Our rationale was that the single ultrasound examination conducted at the first GnRH injection of Ovsynch should correspond to concentrations of progesterone [i.e., the presence (high concentrations) or absence (low concentrations) of a CL detected by ultrasound]. In addition, we anticipated that if heatmount detectors were accurate in detecting prior estrus activity after the second Presynch injection, then an activated detector should correspond to the presence of high progesterone at the initiation of Ovsynch.

The relationship between measured serum progesterone concentrations and the presence of an activated heatmount detector or a detected CL is presented in Table 3. The presence of an activated heatmount detector had little relationship with the circulating concentrations of progesterone. Even cows having very low circulating progesterone $(<0.5 \mathrm{ng} / \mathrm{mL})$ had a high percentage of activated detectors $(141 / 230=61.3 \%)$. Fur- 
Table 4. Accuracy of estimating prior luteal activity in lactating dairy cows by heatmount detectors and transrectal ultrasonography compared with serum concentrations of progesterone

\begin{tabular}{|c|c|c|c|}
\hline \multirow[b]{2}{*}{ Item } & \multicolumn{3}{|c|}{ Method } \\
\hline & Heatmount detector $^{1}$ & Ultrasonography $^{2}$ & Serum progesterone ${ }^{3}$ \\
\hline \multicolumn{4}{|l|}{ Estimates of luteal activity } \\
\hline Correct noncycling & $5.6(59 / 1,060)$ & $12.8^{\mathrm{a}}(137 / 1,067)$ & $16.3(174 / 1,067)$ \\
\hline False positives & $10.9(115 / 1,060)$ & $3.5^{\mathrm{a}}(37 / 1,067)$ & \\
\hline False negatives & $17.6(187 / 1,060)$ & $12.6^{\mathrm{a}}(134 / 1,067)$ & \\
\hline Correct luteal activity & $65.9(699 / 1,060)$ & $71.1^{\mathrm{a}}(759 / 1,067)$ & $83.7(893 / 1,067)$ \\
\hline Overall accuracy & $71.5(758 / 1,060)$ & $84.0^{\mathrm{a}}(896 / 1,067)$ & $100.0(1,067 / 1,067)$ \\
\hline \multicolumn{4}{|l|}{ Measures of accuracy } \\
\hline Sensitivity $^{4}$ & $78.9(699 / 886)$ & $85.0^{\mathrm{a}}(759 / 893)$ & \\
\hline Specificity $^{5}$ & $33.9(59 / 174)$ & $78.7^{\mathrm{a}}(137 / 174)$ & \\
\hline Apparent prevalence 6 & $76.8(814 / 1,060)$ & $74.6(796 / 1,067)$ & \\
\hline Predictive value positive ${ }^{7}$ & $85.9(699 / 814)$ & $95.4^{\mathrm{a}}(759 / 796)$ & \\
\hline Predictive value negative 8 & $24.0(59 / 246)$ & $50.6^{\mathrm{a}}(137 / 271)$ & \\
\hline Simple kappa coefficient ${ }^{9}$ & 0.11 & 0.52 & \\
\hline
\end{tabular}

${ }^{\text {aDifferent }}(P<0.001)$ from heatmount detector.

${ }^{1}$ Cumulative assessment of activated heatmount detectors affixed before first Presynch $\mathrm{PGF}_{2 \alpha}$ injection and read before the second Presynch $\mathrm{PGF}_{2 \alpha}$ injection and first $\mathrm{GnRH}$ injection of the Ovsynch protocol during a 28-d period. Data available for 1,060 cows.

${ }^{2}$ Based on the presence or absence of a corpus luteum (CL) assessed before the first GnRH injection of the Ovsynch protocol. Data available for 1,067 cows.

${ }^{3}$ Based on progesterone concentrations measured in 3 blood samples collected before each Presynch PGF ${ }_{2 \alpha}$ injection and before ultrasonography at the time of the first GnRH injection of the Ovsynch protocol. Data available for 1,067 cows.

${ }^{4}$ Percentage of cows classified as having correct luteal activity by using the heatmount detector (activated or missing) or ultrasonography (presence of a CL) as a proportion of correct luteal activity + number of false negatives.

${ }^{5}$ Percentage of cows classified as having correct noncycling activity by using the heatmount detector (not activated) or ultrasonography (absence of a CL) as a proportion of correct noncycling activity + number of false positives.

${ }^{6}$ Percentage of cows having prior luteal activity by using the heatmount detector (activated or missing) or ultrasonography (presence of a CL) as a proportion of all cows.

${ }^{7}$ Percentage of cows having prior luteal activity by using the heatmount detector (activated or missing) or ultrasonography (presence of a CL) classified correctly based on serum progesterone $\geq 1 \mathrm{ng} / \mathrm{mL}$.

${ }^{8}$ Percentage of cows having no prior luteal activity by using the heatmount detector (not activated) or ultrasonography (absence of a CL) classified correctly based on serum progesterone $<1 \mathrm{ng} / \mathrm{mL}$.

${ }^{9}$ Measure of repeatability in which a value of 1 indicates perfect agreement and 0 indicates the amount of agreement that occurs by chance alone. A kappa value of 0.4 to 0.5 indicates moderate agreement, 0.5 to 0.6 indicates good agreement, and >0.6 indicates excellent agreement (Martin et al., 1987).

ther, cows having greater progesterone concentrations $(\geq 1 \mathrm{ng} / \mathrm{mL}$ ) showed only a slightly greater percentage of activated detectors $(520 / 753=69.1 \%)$.

In contrast, detection of a CL by ultrasound corresponded fairly well to the circulating progesterone concentrations at the onset of treatment (Table 3). For example, among cows having low progesterone concentrations $(<0.5 \mathrm{ng} / \mathrm{mL})$, only $20.8 \%(45 / 216)$ had a visible $\mathrm{CL}$. In contrast, cows having greater circulating progesterone ( $\geq 1 \mathrm{ng} / \mathrm{mL}$ ) at first $\mathrm{GnRH}$ were more likely to have a CL detected by ultrasound $(646 / 695=92.9 \%)$.

Table 4 shows how well a single ultrasound examination or 2 evaluations of heatmount detectors corresponded to whether an individual cow had elevated progesterone concentrations at any of the 3 evaluations (before either Presynch injection and before the first $\mathrm{GnRH}$ injection of Ovsynch). Overall, relative to the 3 progesterone measurements assessed for $28 \mathrm{~d}$ before Ovsynch, heatmount detectors and a single ultrasound exam of ovarian structures underestimated both anovulation and previous luteal activity (Table 4). Variation among herds for the overall accuracy of assessing prior luteal activity (total correct diagnoses of prior noncycling and cycling activity) was evident (Table 5), and may be related to the competency of operators or the stage of luteal development (i.e., a new CL or regressing CL at the time of the exam). Relative to serum concentrations of progesterone, the overall accuracy of heatmount detectors among locations ranged from 49.8 to $86.3 \%$, whereas that of ultrasonography ranged from 68.8 to $90 \%$.

Surprisingly, heatmount detectors were activated in $66 \%(115 / 174)$ of noncycling cows (based on low progesterone in all 3 pretreatment samples), whereas a single 
Table 5. Location accuracy of estimating prior luteal activity by heatmount detectors and transrectal ultrasonography compared with serum concentrations of progesterone ${ }^{1}$

\begin{tabular}{|c|c|c|}
\hline \multirow[b]{2}{*}{ Location $^{2}$} & \multicolumn{2}{|c|}{ Method } \\
\hline & Heatmount detector $^{3}$ & Ultrasonography ${ }^{4}$ \\
\hline IN & & \\
\hline $\begin{array}{l}\text { IN } \\
\text { KS }\end{array}$ & $82.1^{\text {ac }}(64 / 78)$ & $68.8^{\circ}(55 / 80)$ \\
\hline $\begin{array}{l}\text { KS } \\
\text { MI }\end{array}$ & $\begin{array}{l}71.4^{\text {cd }}(155 / 217) \\
86.3^{\text {a }}(132 / 153)\end{array}$ & $\begin{array}{l}84.8^{\mathrm{a}}(184 / 217) \\
856^{\mathrm{a}}(131 / 153)\end{array}$ \\
\hline MN & $71.1^{\mathrm{c}}(138 / 194)$ & $79.9^{\mathrm{b}}(155 / 194)$ \\
\hline MO & $49.8^{\mathrm{b}}(118 / 237)$ & $86.0^{\mathrm{a}}(208 / 242)$ \\
\hline WI & $83.4^{\mathrm{a}}(151 / 181)$ & $90.0^{\mathrm{a}}(163 / 181)$ \\
\hline Total & $71.5(758 / 1,060)$ & $84.0(896 / 1,067)$ \\
\hline
\end{tabular}

${ }^{\mathrm{a}-\mathrm{d}}$ Herd means within method having different superscript letters differ $(P \leq 0.05)$.

${ }^{1}$ Based on progesterone concentrations measured in 3 blood samples collected before each Presynch $\mathrm{PGF}_{2 \alpha}$ injection and before ultrasonography at the time of the first GnRH injection of the Ovsynch protocol. Data available for 1,067 cows.

${ }^{2} \mathrm{IN}=$ Indiana; $\mathrm{KS}$ = Kansas; $\mathrm{MI}=$ Michigan; $\mathrm{MN}=$ Minnesota; $\mathrm{MO}=$ Missouri; $\mathrm{WI}=$ Wisconsin .

${ }^{3}$ Cumulative assessment of activated heatmount detectors affixed before first Presynch $\mathrm{PGF}_{2 \alpha}$ injection and read before the second Presynch $\mathrm{PGF}_{2 \alpha}$ injection and first GnRH injection of the Ovsynch protocol during a 28-d period. Data available for 1,060 cows.

${ }^{4}$ Based on the presence or absence of a corpus luteum assessed before the first GnRH injection of the Ovsynch protocol. Data available for 1,067 cows.

ultrasound examination incorrectly classified noncycling cows only $21 \%(37 / 174)$ of the time. Conversely, ovulatory cows ( $\geq 1 \mathrm{ng} / \mathrm{mL}$ progesterone) were correctly identified $78 \%(694 / 883)$ of the time by heatmount detectors, but $85 \%$ (759/893) were correctly identified by ultrasound. Thus, relative to serum progesterone patterns, the overall accuracy of heatmount detectors was $71.4 \%$ and that of a single ultrasound examination was $84 \%$. Ultrasound differed $(P<0.001)$ from heatmount detectors in every category except for apparent prevalence, including being more $(P<0.001)$ sensitive and specific than heatmount detectors. Particularly striking was the low specificity of the heatmount detectors (only $33.9 \%$ ), corresponding to the inaccuracy of this technique for accurately identifying noncycling cows. The kappa coefficient (0.52) for ultrasound was in a range that indicated good agreement with progesterone concentrations, whereas that of the heatmount detectors (0.11) was in a range that indicated a poor predictive value for progesterone status. As expected, heatmount detectors had greater $(P<0.001)$ rates of false positives (incorrectly identifying prior estrual activity and subsequent luteal activity; 3.1-fold greater) and false negatives (missing prior estrual activity and subsequent luteal activity; 1.4-fold greater) than ultrasound.

\section{Ovarian Characteristics Before Treatment}

Various ovarian traits of cows were assessed before treatment was initiated at 5 locations (Kansas, Michi- gan, Minnesota, Missouri, and Wisconsin). Cows having previous luteal activity (as assessed by serum concentrations of progesterone in 3 previous samples for 28 d) had fewer $(P<0.01)$ numbers of follicles $\geq 10 \mathrm{~mm}$ in diameter before the first GnRH injection at the onset of treatment than did noncycling cows $(1.4 \pm 0.1 ; \mathrm{n}=$ 682 vs. $1.7 \pm 0.1 ; \mathrm{n}=149$ ). Diameter of the largest follicle at the onset of treatment, however, did not differ $(15.6 \pm 0.2 ; \mathrm{n}=630$ vs. $15.4 \pm 0.3 ; \mathrm{n}=137)$ between noncycling and cycling cows, respectively. As expected, the percentage of cows having a CL on the day of treatment was nearly 5 -fold greater $(P<0.001)$ in cycling cows $(85.9 \%)$ compared with noncycling cows (17.7\%). Concentrations of progesterone in cows with no CL averaged $0.6 \pm 0.2 \mathrm{ng} / \mathrm{mL}$, whereas those in cows having a CL averaged $2.4 \pm 0.2 \mathrm{ng} / \mathrm{mL}$. Although concentrations of progesterone were minimal in noncycling cows, some cows had a visible CL, but may have been misclassified as noncycling because blood progesterone was not detectable at sampling times in cows having a newly formed CL or a regressing CL.

The presence of at least 1 large cystic-like follicle $(>25$ $\mathrm{mm}$ ) was noted in 7.3\% (61/836) of evaluated cows. Most $(72 \% ; 44 / 61)$ of these "cystic" cows, however, either had a CL present or had high circulating progesterone concentrations, leaving only 17 cows $(2 \%)$ with a probable follicular cyst.

\section{Ovarian Characteristics in Response to Progesterone}

Our second objective was to determine the effects of progesterone (CIDR insert) in cows identified with or without a CL at the onset of the Ovsynch protocol. This assessment was made (at all 6 locations) by a single ultrasound examination of ovaries. As cited earlier, prior cycling status of some cows was incorrectly categorized by that single examination. The incidence of ovulation in response to the first $\mathrm{GnRH}$ injection was less $(P<0.05)$ in cows with $C L$ absent that were treated with progesterone (CIDR insert) than in cows with CL absent and not receiving a CIDR insert (Table 6). The average incidence of ovulation was less $(P<0.001)$ for cows having a CL than for those without a CL (Table 6). Concentrations of progesterone for cows before treatment were $0.7 \pm 0.2 \mathrm{ng} / \mathrm{mL}$ (no CL + no CIDR), $0.6 \pm$ $0.2 \mathrm{ng} / \mathrm{mL}$ (no CL + CIDR), and $4.0 \pm 0.1 \mathrm{ng} / \mathrm{mL}$ (CL present). Because concentrations of progesterone in ovariectomized cows are $>1 \mathrm{ng} / \mathrm{mL}$ by 5 min and peak $2 \mathrm{~h}$ after insertion of a CIDR (Rathbone et al., 2002), GnRH-induced LH release may be attenuated by elevated concentrations of endogenous or exogenous (via a CIDR) progesterone. A reduced incidence of GnRHinduced ovulation in lactating dairy cows was observed 
Table 6. Ovarian characteristics and fertility in response to presence or absence of a corpus luteum (CL) assessed by transrectal ultrasonography and progesterone treatment [controlled internal drug release (CIDR) insert] at the onset of the Ovsynch protocol

\begin{tabular}{|c|c|c|c|}
\hline \multirow[b]{2}{*}{ Item } & \multicolumn{2}{|c|}{ CL absent ${ }^{1}$} & \multirow[b]{2}{*}{ CL present ${ }^{1}$} \\
\hline & No CIDR & CIDR & \\
\hline Ovulation after first $\mathrm{GnRH},{ }^{2} \%$ & $76.8^{\mathrm{a}}(53 / 69)^{4}$ & $47.1^{\mathrm{b}}(49 / 104)$ & $43.4^{\mathrm{b}, \mathrm{x}}(262 / 604)$ \\
\hline Presence of CL at time of $\mathrm{PGF}_{2 \alpha},{ }^{2} \%$ & $76.8^{\mathrm{a}}(53 / 69)$ & $51.0^{\mathrm{b}}(53 / 104)$ & $95.7^{\mathrm{c}, \mathrm{x}}(584 / 610)$ \\
\hline $\mathrm{CL}$ at time of $\mathrm{PGF}_{2 \alpha},{ }^{3} \mathrm{n}$ & $0.9^{\mathrm{a}} \pm 0.1(55)^{5}$ & $0.7^{\mathrm{a}} \pm 0.1$ & $1.4^{\mathrm{b}} \pm 0.1(450)$ \\
\hline $\begin{array}{l}\text { Diameter of ovulatory follicle at second } \\
\mathrm{GnRH}^{2} \mathrm{~mm}\end{array}$ & $16.7^{\mathrm{a}} \pm 0.4(65)$ & $16.2^{\mathrm{a}} \pm 0.4(103)$ & $15.2^{\mathrm{b}, \mathrm{x}} \pm 0.1(588)$ \\
\hline Ovulation after second $\mathrm{GnRH}, 2 \%$ & $77.9(53 / 68)$ & $75.0(78 / 104)$ & $80.7(488 / 605)$ \\
\hline Pregnancies per AI at d $33, \%$ & $24.1^{\mathrm{a}}(28 / 116)$ & $32.3^{\mathrm{b}}(50 / 155)$ & $38.0^{\mathrm{b}, \mathrm{x}}(303 / 799)$ \\
\hline Pregnancies per AI at $d 61, \%$ & $20.7^{\mathrm{a}}(24 / 116)$ & $29.0^{\mathrm{b}}(45 / 155)$ & $34.2^{\mathrm{b}, \mathrm{x}}(273 / 799)$ \\
\hline Pregnancy loss from d 33 to $61, \%$ & $14.3(4 / 28)$ & $10.0(5 / 50)$ & $9.9^{\mathrm{y}}(30 / 303)$ \\
\hline
\end{tabular}

${ }^{\mathrm{a}-\mathrm{c}}$ Means having different superscript letters differ $(P \leq 0.05)$.

${ }^{x}$ Different $(P \leq 0.05)$ from cows with CL absent.

${ }^{\mathrm{y}}$ Tended $(P \leq 0.10)$ to differ from cows with CL absent.

${ }^{1}$ Absence or presence of a CL as assessed by transrectal ultrasonography at the first GnRH injection of the Ovsynch protocol.

${ }^{2}$ Assessed at 3 of 6 locations.

${ }^{3}$ Assessed at 2 of 6 locations.

${ }^{4}$ Percentage and number of observations.

${ }^{5}$ Mean \pm SE and number of observations.

previously for cows concurrently treated with $\mathrm{GnRH}$ and a CIDR insert compared with cows treated with GnRH (68 vs. 87\%, respectively; Galvão et al., 2004). Taken together, that study (Galvão et al., 2004) and the current study indicate that cows having elevated progesterone (CL present) or those administered a progesterone insert concurrently with a $\mathrm{GnRH}$ injection may have a reduced incidence of ovulation compared with cows having low progesterone or no CL.

Diameter of the ovulatory follicle, as assessed before the second GnRH injection, was smaller $(P<0.001)$ in cows with CL present than for cows with CL absent, regardless of CIDR treatment (Table 6). The incidence of ovulation of that follicle, as assessed $5 \mathrm{~d}$ later (after TAI), did not differ among cows having or not having a CL (Table 6) at the onset of treatment.

\section{Fertility in Response to Progesterone}

Pregnancies per AI at d 33 and 61 and pregnancy loss in 1,068 cows ( 4 were culled before pregnancy diagnosis) during that interval are summarized in Table 6. Treatment with a CIDR in cows with a CL absent increased $(P \leq 0.05) \mathrm{P} / \mathrm{AI}$ at either 33 or $61 \mathrm{~d}$ after AI (Table 6), but did not differ from that of cows with a CL present. Pregnancy loss did not differ for cows with a CL absent that either received or did not receive a CIDR. In contrast, pregnancy loss tended $(P<0.10)$ to be less for cows with a CL present than for those in which a CL was not detected before treatment. Cows requiring no calving assistance $(\mathrm{CDS}=1)$ subsequently had greater
$(P<0.05) \mathrm{P} / \mathrm{AI}$ than those requiring some $(\mathrm{CDS}>1)$ assistance $(42.7 \% ; \mathrm{n}=693$ vs. $34.3 \% ; \mathrm{n}=375)$, respectively.

A CIDR treatment $\times$ location interaction tended $(P=$ 0.08 ) to occur (Table 7) for P/AI at d 33. Pregnancies per AI for cows with a CL absent that were treated with a CIDR insert were numerically greater at 4 of 6 locations than for cows with a CL absent that were not treated with progesterone.

\section{Time of Insemination}

Our third objective was to determine whether the time of AI relative to the second GnRH injection ( 0 vs. $24 \mathrm{~h}$ ) altered P/AI (Table 8). Herd had no significant effect in the statistical model for P/AI at $d$ 33. A tendency $(P=0.11)$ was detected for a herd $\times$ time of AI interaction. In contrast, the timing of $\mathrm{AI}$ had no effect on P/AI $(P=0.57)$. The largest numerical difference in $\mathrm{P} / \mathrm{AI}$ between the $2 \mathrm{AI}$ times was observed in cows with a CL present $[0 \mathrm{~h}=35.4 \%(142 / 401)$ vs. $24 \mathrm{~h}=40.8 \%$ (161/395)].

\section{Concentrations of Progesterone}

Pretreatment progesterone patterns and incidence of ovulation in response to the first $\mathrm{GnRH}$ injection influenced P/AI at d 33 (Table 9). When ovulation occurred in response to the first GnRH injection, P/AI was $25 \%$ greater $(P<0.05)$ than when ovulation did not occur (41.6 vs. $33.3 \%$, respectively). In 6 of the 8 
Table 7. Presence or absence of luteal structure(s) before treatment and pregnancies per AI at d 33 after timed insemination

\begin{tabular}{|c|c|c|c|c|c|}
\hline \multirow[b]{2}{*}{ Location $^{1}$} & \multicolumn{3}{|c|}{ CL absent ${ }^{2}$} & \multirow[b]{2}{*}{ CL present ${ }^{2}$} & \multirow[b]{2}{*}{ Overall } \\
\hline & No $\mathrm{CIDR}^{3}$ & CIDR & No CL total & & \\
\hline IN & $22.2(2 / 9)$ & $18.8(3 / 16)$ & $20.0(5 / 25)$ & $45.5(25 / 55)$ & $37.5(30 / 80)$ \\
\hline KS & $21.7(5 / 23)$ & $26.1(6 / 23)$ & $23.9(11 / 46)$ & $48.0(82 / 171)$ & $42.9(93 / 217)$ \\
\hline MI & $12.5(2 / 16)$ & $58.3(7 / 12)$ & $32.1(9 / 28)$ & $36.8(46 / 125)$ & $35.9(55 / 153)$ \\
\hline MN & $21.6(8 / 37)$ & $32.4(11 / 34)$ & $26.8(19 / 71)$ & $30.9(38 / 123)$ & $29.4(57 / 194)$ \\
\hline MO & $35.0(7 / 20)$ & $29.0(18 / 62)$ & $30.5(25 / 82)$ & $34.4(55 / 160)$ & $33.1(80 / 242)$ \\
\hline WI & $36.4(4 / 11)$ & $62.5(5 / 8)$ & $47.4(10 / 21)$ & $35.2(57 / 165)$ & $36.3(66 / 182)$ \\
\hline Overall & $24.1(28 / 116)$ & $32.3(50 / 155)$ & $28.9^{\mathrm{a}}(79 / 273)$ & $38.0^{\mathrm{b}}(303 / 799)$ & \\
\hline
\end{tabular}

\footnotetext{
${ }^{\mathrm{a}, \mathrm{b}}$ Overall means differed $(P \leq 0.05)$; however, an interaction of treatment $\times$ location tended $(P=0.08)$ to occur.

${ }^{1} \mathrm{IN}=$ Indiana $; \mathrm{KS}=$ Kansas $; \mathrm{MI}=$ Michigan $; \mathrm{MN}=$ Minnesota $; \mathrm{MO}=$ Missouri $; \mathrm{WI}=$ Wisconsin.

${ }^{2}$ Absence or presence of a corpus luteum (CL) assessed by transrectal ultrasonography at the first GnRH injection of the Ovsynch protocol.

${ }^{3} \mathrm{CIDR}=$ controlled internal drug-release insert.
}

pretreatment progesterone patterns, $\mathrm{P} / \mathrm{AI}$ were greater when ovulation had occurred in response to the first GnRH injection (Table 9).

Nearly $90 \%$ (708/796) of cows with a CL present had elevated progesterone at the onset of the Ovsynch protocol, whereas $72 \%$ of all cows had elevated progesterone at that time and $22 \%$ of cows with no detected CL had elevated progesterone. Although the numbers of observations were limited, cows treated with progesterone had numerically greater P/AI than those not treated with a CIDR insert in 6 (HHH, LHH, LLH, HHL, LHL, and HLL; Table 9) of the 8 permutations. Three of these 6 patterns in which P/AI were numerically greater for CIDR-treated cows included cows with low progesterone at the onset of Ovsynch, whereas the other 3 patterns included cows that had 1 or 2 low progesterone concentrations at the first or second sampling times, but had elevated progesterone at the onset of treatment. Pregnancies per AI in noncycling cows (LLL; Table 9) were not improved in response to treatment with progesterone.

Table 8. Timing of AI relative to the second GnRH injection of Ovsynch and pregnancies per AI at d 33

\begin{tabular}{llc}
\hline & \multicolumn{2}{c}{ Timing of AI after $\mathrm{GnRH},{ }^{2} \mathrm{~h}$} \\
\cline { 2 - 3 } Location $^{1}$ & 0 & 24 \\
\hline IN & $46.2(18 / 39)$ & $29.3(12 / 41)$ \\
KS & $39.8(43 / 108)$ & $45.9(50 / 109)$ \\
MI & $27.6(21 / 76)$ & $44.2(34 / 77)$ \\
MN & $30.9(29 / 94)$ & $28.0(28 / 100)$ \\
MO & $28.5(35 / 123)$ & $37.8(45 / 119)$ \\
WI & $37.8(35 / 92)$ & $34.8(33 / 94)$ \\
Overall & $34.0(181 / 532)$ & $37.4(202 / 540)$ \\
\hline \multicolumn{2}{r}{${ }^{1} \mathrm{IN}=$ Indiana; KS $=$ Kansas; $\mathrm{MI}=$ Michigan; MN $=$ Minnesota; } \\
\multicolumn{2}{c}{ MO = Missouri; WI = Wisconsin. }
\end{tabular}

Further, when cows with a CL absent and having elevated progesterone at the onset of treatment were treated with the CIDR, P/AI did not differ from those of cows with a CL present (first subtotal in Table 9). In contrast, when cows with a CL absent and having low progesterone at the onset of treatment were treated with a CIDR, P/AI did not differ from those of the other 2 treatments (second subtotal in Table 9).

The relationship of pretreatment cycling status and the presence of high vs. low concentrations of progesterone before the $\mathrm{PGF}_{2 \alpha}$ injection of Ovsynch was examined further (Table 10). Despite the presence of the CIDR insert, 34.7\% (30 noncycling and 10 cycling cows; Table 10) of 155 CIDR-treated cows with a CL absent had concentrations of progesterone $<1 \mathrm{ng} / \mathrm{mL}$ at insert removal, indicating that these cows did not have a functional CL. Concentrations of progesterone in CIDRtreated cows bearing a luteal structure are generally not different before the insert is removed but differ after insert removal when a CL is present (Stevenson et al., 2006). Further, because identifying the cycling status was less accurate by 1 ultrasound examination relative to 3 estimates of serum concentrations of progesterone in these cows, 44.5\% (69 cycling cows of 155 cows with CL absent) treated with a CIDR insert had elevated pretreatment concentrations of progesterone at some time during the $28 \mathrm{~d}$ before treatment (indicating prior cyclicity). In addition, 56\% (65 cycling cows of 116 cows with CL absent) not treated with a CIDR insert met this criterion and were cycling before Ovsynch.

The effects of treatment of truly noncycling cows are summarized in the top 3 lines of Table 10, and similar effects of truly cycling cows are summarized in the bottom 3 lines of Table 10. Pregnancies per AI in noncycling cows treated or not treated with a CIDR insert did not 
Table 9. Pregnancies per AI at d 33 after timed insemination according to the progesterone pattern before onset of treatment and ovulation status after the first $\mathrm{GnRH}$ injection

\begin{tabular}{|c|c|c|c|c|c|}
\hline \multirow{2}{*}{$\begin{array}{l}\text { Progesterone } \\
\text { pattern }^{1}\end{array}$} & \multicolumn{2}{|c|}{ CL absent $^{2}$} & \multirow[b]{2}{*}{ CL present ${ }^{2}$} & \multirow{2}{*}{$\begin{array}{l}\text { Ovulated } \\
\text { after 1st } \\
\text { GnRH }^{4}\end{array}$} & \multirow{2}{*}{$\begin{array}{l}\text { Pregnancies } \\
\text { per AI }\end{array}$} \\
\hline & No CIDR $^{3}$ & CIDR & & & \\
\hline & & $\%(\mathrm{n})$ & - & & $-\%(\mathrm{n})-$ \\
\hline \multirow[t]{2}{*}{$\mathrm{HHH}$} & $20.0(2 / 10)$ & $42.9(6 / 14)$ & $43.0(141 / 328)$ & No & $39.7(58 / 146)$ \\
\hline & & & & Yes & $43.3(61 / 141)$ \\
\hline $\mathrm{LHH}$ & $0.0(0 / 7)$ & $60.0(6 / 10)$ & $43.2(99 / 229)$ & $\begin{array}{l}\text { No } \\
\text { Yes }\end{array}$ & $\begin{array}{l}40.7(46 / 113) \\
51.4(36 / 70)\end{array}$ \\
\hline \multirow[t]{2}{*}{ HLH } & - & $0.0(0 / 1)$ & $32.6(14 / 43)$ & No & $22.7(5 / 22)$ \\
\hline & & & & Yes & $55.5(5 / 9)$ \\
\hline \multirow[t]{2}{*}{ LLH } & $25.0(2 / 8)$ & $30.0(3 / 10)$ & $26.9(29 / 108)$ & No & $28.3(15 / 53)$ \\
\hline & & & & Yes & $22.6(7 / 31)$ \\
\hline \multirow[t]{2}{*}{ Subtotal } & $16.0^{\mathrm{a}}(4 / 25)$ & $42.9^{b}(15 / 35)$ & $40.0^{\mathrm{b}}(283 / 708)$ & No & $37.1(124 / 334)$ \\
\hline & & & & Yes & $43.4(109 / 251)$ \\
\hline \multirow[t]{2}{*}{ HHL } & $33.3(6 / 18)$ & $41.2(7 / 17)$ & $20.0(5 / 25)$ & No & $11.8(2 / 17)$ \\
\hline & & & & Yes & $46.4(13 / 28)$ \\
\hline \multirow[t]{2}{*}{ LHL } & $12.5(1 / 8)$ & $33.3(3 / 9)$ & $21.0(4 / 19)$ & No & $12.5(1 / 8)$ \\
\hline & & & & Yes & $29.4(5 / 17)$ \\
\hline \multirow[t]{2}{*}{ HLL } & $28.6(4 / 14)$ & $62.5(5 / 8)$ & $14.3(1 / 7)$ & No & $50.0(3 / 6)$ \\
\hline & & & & Yes & $41.7(5 / 12)$ \\
\hline \multirow[t]{2}{*}{ LLL } & $25.5(13 / 51)$ & $23.3(20 / 86)$ & $27.0(10 / 37)$ & No & $16.0(8 / 50)$ \\
\hline & & & & Yes & $34.0(18 / 53)$ \\
\hline \multirow[t]{2}{*}{ Subtotal } & $26.4^{\mathrm{a}}(24 / 91)$ & $29.2^{\mathrm{a}}(35 / 120)$ & $22.7^{\mathrm{a}}(20 / 88)$ & No & $17.3(14 / 81)$ \\
\hline & & & & Yes & $37.2(41 / 110)$ \\
\hline \multirow[t]{2}{*}{ Total } & $24.1(28 / 116)$ & $32.3(50 / 155)$ & $38.1(303 / 796)$ & No & $33.3(138 / 415)$ \\
\hline & & & & Yes & $41.6^{* *}(150 / 361)$ \\
\hline
\end{tabular}

a,b Treatment $\times$ progesterone pattern interaction $(P<0.05)$.

${ }^{1}$ Based on progesterone concentrations measured in blood serum collected before each Presynch $\mathrm{PGF}_{2 a}$ injection and before the first $\mathrm{GnRH}$ injection of the Ovsynch protocol ( $\mathrm{L}=$ concentrations of progesterone $<1 \mathrm{ng} / \mathrm{mL} ; \mathrm{H}=\geq 1 \mathrm{ng} / \mathrm{mL}$ ).

${ }^{2}$ Absence or presence of a corpus luteum (CL) assessed by transrectal ultrasonography at the first GnRH injection of the Ovsynch protocol.

${ }^{3} \mathrm{CIDR}=$ controlled internal drug-release insert.

${ }^{4}$ Assessed at 3 of 6 locations.

**Different $(P<0.01)$ from cows that did not ovulate.

Table 10. Pregnancies per AI at d 33 after timed insemination according to pretreatment luteal activity and concentrations of progesterone at the time of $\mathrm{PGF}_{2 \alpha}$ injection

\begin{tabular}{|c|c|c|c|c|c|}
\hline \multirow{2}{*}{$\begin{array}{l}\text { Pretreatment } \\
\text { status }^{1}\end{array}$} & \multirow{2}{*}{$\begin{array}{l}\text { Serum progesterone } \\
\text { before } \mathrm{PGF}_{2 \alpha}{ }^{2}\end{array}$} & \multicolumn{2}{|c|}{ CL absent ${ }^{3}$} & \multirow[b]{2}{*}{ CL present ${ }^{3}$} & \multirow{2}{*}{$\begin{array}{c}\text { Pretreatment } \\
\text { status total }\end{array}$} \\
\hline & & No CIDR & CIDR & & \\
\hline & & & & $\%(\mathrm{n})$ & \\
\hline Noncycling & $\begin{array}{l}\text { High } \\
\text { Low } \\
\text { Subtotal }\end{array}$ & $\begin{array}{l}29.4(10 / 34) \\
17.6(3 / 17) \\
25.5^{\mathrm{a}}(13 / 51)\end{array}$ & $\begin{array}{c}32.1(18 / 56) \\
6.7(2 / 30) \\
23.3^{\mathrm{a}}(20 / 86)\end{array}$ & $\begin{array}{l}32.0(8 / 25) \\
16.7(2 / 12) \\
27.0^{\mathrm{a}}(10 / 37)\end{array}$ & $24.7^{\mathrm{x}}(43 / 174)$ \\
\hline Cycling & $\begin{array}{l}\text { High } \\
\text { Low } \\
\text { Subtotal }\end{array}$ & $\begin{array}{c}25.9(14 / 54) \\
9.1(1 / 11) \\
23.1^{\mathrm{a}}(15 / 65)\end{array}$ & $\begin{array}{l}44.1(26 / 59) \\
40.0(4 / 10) \\
43.5^{\mathrm{b}}(30 / 69)\end{array}$ & $\begin{array}{l}40.2(262 / 651) \\
28.7(31 / 108) \\
38.6^{\mathrm{b}}(293 / 759)\end{array}$ & $37.8^{\mathrm{y}}(338 / 893)$ \\
\hline
\end{tabular}

${ }^{\mathrm{a}, \mathrm{b}}$ Treatment $\times$ cycling status interaction $(P=0.08)$.

${ }^{\mathrm{x}, \mathrm{y}}$ Pretreatment cycling status differed $(P<0.05)$.

${ }^{1}$ Based on progesterone concentrations measured in 3 serum samples collected before each Presynch $\mathrm{PGF}_{2 \alpha}$ injection and before the first $\mathrm{GnRH}$ injection of Ovsynch.

${ }^{2}$ Low $=$ concentrations of progesterone $<1 \mathrm{ng} / \mathrm{mL}$; high $=\geq 1 \mathrm{ng} / \mathrm{mL}$ at $\mathrm{PGF}_{2 \alpha}$ injection of the Ovsynch protocol.

${ }^{3}$ Absence or presence of a corpus luteum (CL) as assessed by transrectal ultrasonography at the first GnRH injection of the Ovsynch protocol. Some cows treated with a controlled internal drug-release (CIDR) insert may have had elevated progesterone because of the CIDR insert. 
differ from those in cows with a CL present, regardless of progesterone concentrations at the time of the $\mathrm{PGF}_{2 \alpha}$ injection (first subtotal in Table 10). In contrast, regardless of progesterone concentrations at the time of the $\mathrm{PGF}_{2 \alpha}$ injection, cows with a CL absent that were treated with a CIDR and cows with a CL present had greater P/AI than cows with a CL absent that were not treated with a CIDR (second total in Table 10). Overall, cows having prior cycling activity, as assessed by 3 estimates of serum progesterone before treatment, had $53 \%$ greater $(P<0.001) \mathrm{P} / \mathrm{AI}$ at $\mathrm{d} 33$ than did those without prior luteal activity (37.8 vs. $24.7 \%$; Table 10 ). This advantage in P/AI for prior cycling cows was consistent for cows with a CL present and for cows with a CL absent that were treated with progesterone, but not for cows with a CL absent that were not treated with progesterone (Table 10).

The CIDR treatment of noncycling cows not having a functional CL before the $\mathrm{PGF}_{2 \alpha}$ injection improved $\mathrm{P} /$ AI in a study by Stevenson et al. (2006), but not in the present study (Table 10) or in another large study (Moreira et al., 2004a). Further, CIDR treatment in previously cycling cows having low concentrations of progesterone before $\mathrm{PGF}_{2 \alpha}$ injection (early CL regression) had numerically greater P/AI in the present study, as in a previous study (Stevenson et al., 2006). Interpretation of the results in the previous study (Stevenson et al., 2006) suggested that the CIDR insert should improve P/AI in cows having no active CL or low progesterone before the $\mathrm{PGF}_{2 \alpha}$ injection, regardless of previously cycling or luteal status. In the present study, we could only verify improved P/AI for previously cycling cows having low progesterone (early CL regression), as well as high progesterone at CIDR insert removal.

Concentrations of progesterone in serum $2 \mathrm{~d}$ before the second GnRH injection (day of the $\mathrm{PGF}_{2 \alpha}$ injection of Ovsynch and removal of the CIDR inserts), at the time of the second GnRH injection, and 5 and $12 \mathrm{~d}$ later are illustrated in Figure 2. At insert removal, cows with a CL absent that were treated with CIDR inserts had concentrations of progesterone that did not differ from those in cows without inserts, but cows in both treatments had less $(P<0.05)$ progesterone than did cows with a CL present. This same pattern existed $48 \mathrm{~h}$ later when the second GnRH injection was given $(0 \mathrm{~h})$. At 5 $\mathrm{d}$ after AI, no differences in progesterone concentration were detected among treatments, but at $12 \mathrm{~d}$ after the second GnRH injection or at 11 to $12 \mathrm{~d}$ after AI, cows with a CL absent that were treated with a CIDR had greater $(P<0.05)$ concentrations of progesterone than did cows with a CL present. The greater progesterone $12 \mathrm{~d}$ later was similar to an earlier report (Melendez et al., 2006) in which cows treated with CIDR inserts

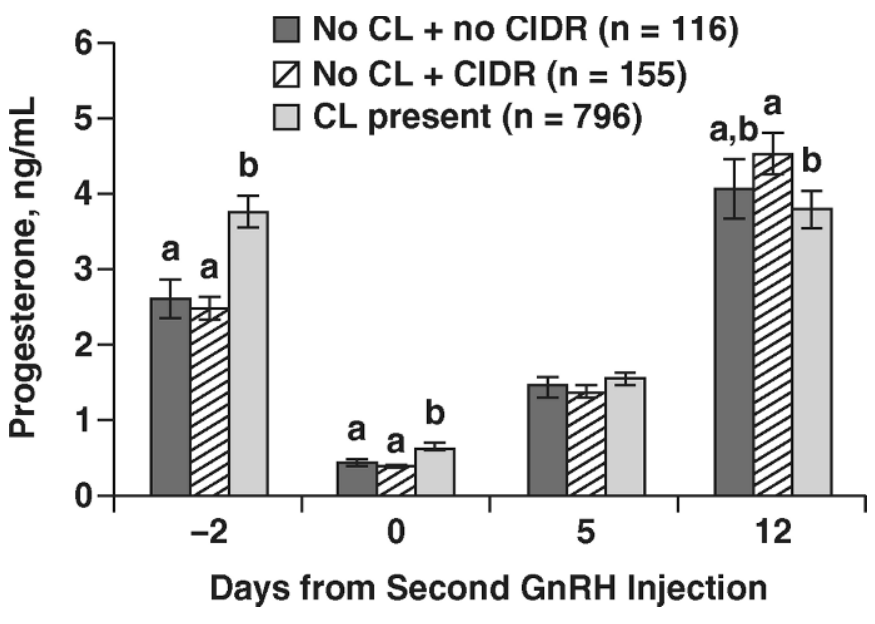

Figure 2. Concentrations of progesterone in serum of lactating dairy cows before injections of $\mathrm{PGF}_{2 \alpha}$ [time of progesterone controlled internal drug-release (CIDR) insert removal; $d-2]$ and the second GnRH injection (d 0), and at 5 and $12 \mathrm{~d}$ after GnRH. Differences among treatments are indicated $\left({ }^{\mathrm{ab}} P<0.05\right)$.

during the Ovsynch protocol had greater progesterone concentrations than did control cows, regardless of their pregnancy status. It seems that maturing follicles exposed to supplemental progesterone during CIDR treatment may, after ovulation, differentiate into CL having a greater progesterone secretory capacity.

As expected, pregnancy status had no effect on concentrations of progesterone at $5 \mathrm{~d}$ after the second GnRH, but at $12 \mathrm{~d}$, pregnant cows had greater $(P<$ 0.001 ) concentrations of progesterone than did nonpregnant cows $(4.7 \pm 0.2 ; \mathrm{n}=686$ vs. $3.6 \pm 0.1 \mathrm{ng} / \mathrm{mL} ; \mathrm{n}=381)$.

\section{General Discussion}

Our first objective was to determine the accuracy of using heatmount detectors and ultrasound to identify noncycling cows. Another study (Silva et al., 2007) concluded that applying ultrasound at the onset of the Ovsynch protocol slightly overestimated the proportion of noncycling cows, but because all noncycling cows were identified by ultrasound, it could be used in field conditions to target specialized treatments for noncycling cows. In the present study, only 7\% (49/695) of cows having high progesterone at the first GnRH treatment did not have an ultrasonically detected CL, again indicating that most cows with elevated progesterone will have a CL detected by ultrasound (Table 3). This accuracy, however, becomes less impressive when this single ultrasound examination is used to detect cows that had ovulated at any time during the $28 \mathrm{~d}$ before initiating Ovsynch, with 15\% (134/893) of previously cycling cows having no CL detected (Table 4). Further, in contrast to Silva et al. (2007), not all noncycling cows 
were correctly identified by ultrasound in our study by using the single progesterone value at the time of first GnRH $(75 / 273=27.5 \%$ of noncycling cows with CL). Nevertheless, the most striking discrepancy found in our study was when comparisons were made between cyclicity status and activation of the heatmount detectors. Accuracy of heatmount detectors has been reported to be quite variable, ranging from 36 to $80 \%$, and was only 56 to $94 \%$ efficient in identifying all estrual activity (Stevenson, 2001). In our study, there was almost no relationship between activation of the heatmount detectors during the Presynch protocol and the cyclicity status of cows. Indeed, the specificity of this technique was only $33.9 \%$, with a kappa coefficient (0.11) that indicated almost no predictive value of heatmount activation for cyclicity status. Further, more than $60 \%$ of noncycling cows had activated heatmount devices. Breeding of these noncycling cows having activated heatmount devices likely would have resulted in few P/AI. Nevertheless, the heatmount devices correctly predicted cyclicity in $78.5 \%$ of cycling cows, and insemination of these cows based on the activated heatmount device may have produced reasonable fertility. These results raise an interesting question of whether a thorough analysis of other estrus-detection methods, such as the ubiquitously used tail chalk, might be equally inaccurate in identifying noncycling cows, producing a reduction in fertility in cows inseminated after "detection" with these methods.

Although ultrasound was not $100 \%$ accurate when attempting to determine prior estrual activity, fertility benefits that accrued from applying a CIDR to lactating cows in the present study were limited to those previously cycling cows not having a CL at the onset of treatment. Therefore, the accuracy of using ultrasound eliminated the unneeded use of CIDR inserts in $84 \%$ of cows with a CL present (796 of 951 cows; Table 9), in which no P/AI increase likely would have been realized. Pregnancies per AI at $\mathrm{d} 33$ were greater for cows with a CL absent (32.3\%) that were treated with progesterone than for cows with a CL absent that were not treated (24.1\%; Table 6). It is clear that regardless of progesterone concentrations at the time of the $\mathrm{PGF}_{2 \alpha}$ injection of Ovsynch, previously cycling cows benefited by treatment with a CIDR compared with those not treated with a CIDR (Table 10).

We (Stevenson et al., 2006) previously reported that P/AI were improved in 2 categories of cows treated with a CIDR insert at the onset of the Ovsynch protocol: 1) noncycling cows before the onset of Ovsynch and no CL induced in response to the first GnRH injection of Ovsynch (33 vs. 17\%); and 2) cycling cows in which early luteolysis occurred before the $\mathrm{PGF}_{2 \alpha}$ injection of Ovsynch (38 vs. 19\%), respectively. The present study fails to show any benefit for cows in the former status (see pretreatment noncycling cows having low progesterone before $\mathrm{PGF}_{2 \alpha}$ injection in Table 10), but corroborates the latter status, in which P/AI for previously cycling cows treated with CIDR inserts and having low concentrations of progesterone before the $\mathrm{PGF}_{2 \alpha}$ injection of the Ovsynch protocol were improved (Table 10). The latter observation also confirms improvement in P/AI for CIDR-treated cows initiating the Ovsynch protocol in late diestrus (Thatcher et al., 2006), whose CL likely regresses spontaneously during the CIDR treatment. Nevertheless, the CIDR-induced reduction in ovulation to the first GnRH treatment (76.8 vs. $47.1 \%$ ) raises the interesting possibility that some of the positive effects of progesterone supplementation may be offset by a negative effect of CIDR on GnRH-induced ovulation. Perhaps alternative timing of CIDR insertion is needed to realize the full benefit of this insert.

Another difference between the present study and our previous study (Stevenson et al., 2006) was the addition of Presynch before applying the TAI protocol. We would not expect Presynch to influence noncycling cows because noncycling cows have no CL to regress in response to Presynch $\mathrm{PGF}_{2 \alpha}$ injections. In contrast, Presynch should have changed the proportion of cows having a CL at the onset of the Ovsynch protocol (ElZarkouny et al., 2004). Other published reports in which progesterone was applied to cows confirm these inconsistent responses. In one study (experiment 1 of El-Zarkouny et al., 2004), conception rates were improved by adding a CIDR insert compared with cows inseminated at estrus or after the Ovsynch protocol. In a 5-location study conducted during summer in Mexico, in which cows were inseminated by using an Ovsynch protocol, conception rates were improved only in firstlactation cows in which a CIDR insert also was included, but the CIDR insert had no positive effect in noncycling cows (Moreira et al., 2004a). In another study conducted in Mexico, in which estrous cycles were presynchronized (Presynch), with the second Presynch injection administered $12 \mathrm{~d}$ before initiating the Ovsynch protocol in all cows, addition of a CIDR insert improved conception rates (Moreira et al., 2004b), whereas no positive effect occurred in 3 other studies applying similar treatments (experiment 2 of El-Zarkouny et al., 2004; Galvão et al., 2004), unless cows were in late diestrus at the time of CIDR insertion (Thatcher et al., 2006).

Our third objective to alter the timing of AI relative to the second GnRH injection of Ovsynch failed to detect any differences in P/AI when cows were inseminated either concurrently with that injection or $24 \mathrm{~h}$ later. These findings are consistent with the first report of variable times of AI (Pursley et al., 1998), in which cows 
inseminated $16 \mathrm{~h}$ after $\mathrm{GnRH}$ produced greater P/AI than did those cows inseminated at $0,8,24$, and $32 \mathrm{~h}$. Numerically, the 24-h insemination was 4 percentage points greater than the 0 -h insemination in that study and was 3.4 percentage units greater in the present study (Table 8), when all cows were combined. In another study (Portaluppi and Stevenson, 2005), in which GnRH was administered at $48 \mathrm{~h}$ after $\mathrm{PGF}_{2 \alpha}$ and cows were inseminated at 48 or $72 \mathrm{~h}, \mathrm{P} / \mathrm{AI}$ in cows were similar at 23 and $24 \%$, respectively, but improved if both GnRH and AI occurred at $72 \mathrm{~h}$ (31\%). Similarly, Cornwell et al. (2006) failed to detect any differences in fertility when cows were bred at the same time as the second GnRH or $24 \mathrm{~h}$ later. Recently, however, Brusveen et al. (2006) found that cows treated with the second $\mathrm{GnRH}$ injection at $56 \mathrm{~h}$ after $\mathrm{PGF}_{2 \alpha}$ and inseminated $16 \mathrm{~h}$ later had markedly improved P/AI compared with cows inseminated at 0 or $24 \mathrm{~h}$ relative to $\mathrm{GnRH}$ administered at $48 \mathrm{~h}$ after $\mathrm{PGF}_{2 \alpha}$.

In summary, identification of noncycling cows was more accurate with a single ultrasound examination than when using heatmount detectors. When lactating dairy cows were found to have no CL (but had evidence of increased concentrations of progesterone in blood serum for $28 \mathrm{~d}$ before initiating the Ovsynch protocol) at the onset of the Ovsynch protocol and were treated with progesterone (via a CIDR insert), P/AI were greater than those of similar cows with a CL absent that were not treated with a CIDR insert. Pregnancies per AI of cows with a CL absent that were treated with a CIDR insert did not differ from those of cows having a CL at initiation of the TAI protocol. Our present study and another one (experiment 2 of El-Zarkouny et al., 2004) found no evidence to support 3 previous studies (Galvão et al., 2004; Moreira et al., 2004a; Stevenson et al., 2006) reporting that including progesterone in a TAI protocol for previously noncycling cows is warranted, regardless of luteal status before the $\mathrm{PGF}_{2 \alpha}$ injection of the Ovsynch protocol. Pregnancy per AI of cows inseminated at 0 vs. $24 \mathrm{~h}$ after the second $\mathrm{GnRH}$ injection did not differ significantly.

\section{ACKNOWLEDGMENTS}

We acknowledge the following individuals for their assistance in conducting this study: M. A. Portaluppi (Kansas), I. Vanderwerff (Kansas), J. Bader (Missouri), J. Denbigh (Missouri), E. Adkins (Missouri), S. Bird (Minnesota), E. Carotti (Minnesota), A. DiCostanzo (Minnesota), N. DiLorenzo (Minnesota), R. Gill (Minnesota), B. Lovaas (Minnesota), D. Millen (Minnesota), and R. Pacheco (Minnesota). The authors thank the following dairy cooperators who participated in this study: Sunny Ridge Dairy LLC (Francesville, IN), Nobis
Dairy Farm (St. Johns, MI), Gar-Linn Dairy Farms Inc. (Eyota, MN), and Nehl's Brothers Dairy (Juneau, WI).

\section{REFERENCES}

Brusveen, D. J., A. P. Cunha, C. D. Silva, P. M. Cunha, R. A. Sterry, E. P. B. Silva, J. N. Guenther, and M. C. Wiltbank. 2006. Effects on conception rates of lactating dairy cows by altering the time of the second GnRH and AI during Ovsynch. J. Dairy Sci. 89(Suppl. 1):150. (Abstr.)

Butler, W. R., and R. D. Smith. 1989. Interrelationships between energy balance and postpartum reproductive function in dairy cattle. J. Dairy Sci. 72:767-783.

Cornwell, J. M., M. L. McGilliard, R. Kasimanickam, and R. L. Nebel. 2006. Effect of sire fertility and timing of artificial insemination in a Presynch + Ovsynch protocol on first-service pregnancy rates. J. Dairy Sci. 89:2473-2478.

El-Zarkouny, S. Z., J. A. Cartmill, B. A. Hensley, and J. S. Stevenson. 2004. Presynchronization of estrous cycles before Ovsynch and progesterone in dairy cows: Ovulation, pregnancy rates, and embryo survival. J. Dairy Sci. 87:1024-1037.

Folman, Y., M. Kaim, Z. Herz, and M. Rosenberg. 1990. Comparison of methods for the synchronization of estrous cycles in dairy cows. 2. Effects of progesterone and parity on conception. J. Dairy Sci. 73:2817-2825.

Fonseca, F. A., J. H. Britt, B. T. McDaniel, J. C. Wilk, and A. H. Rakes. 1983. Reproductive traits of Holsteins and Jerseys. Effects of age, milk yield, and clinical abnormalities on involution of cervix and uterus, ovulation, estrous cycles, detection of estrus, conception rate, and days open. J. Dairy Sci. 66:1128-1147.

Galvão, K. N., J. E. P. Santos, S. O. Juchem, R. L. A. Cerri, A. C. Coscioni, and M. Villaseñor. 2004. Effect of addition of a progesterone intravaginal insert to a timed insemination protocol using estradiol cypionate on ovulation rate, pregnancy rate, and late embryonic loss in lactating dairy cows. J. Anim. Sci. 82:35083517.

Kirby, C. J., M. F. Smith, D. H. Keisler, and M. C. Lucy. 1997. Follicular formation in lactating dairy cows treated with sustained-release bovine somatotropin. J. Dairy Sci. 80:273-285.

Martin, S. W., A. H. Meek, and P. Willeberg. 1987. Measurement of disease frequency and production. Pages $63-75$ in Veterinary Epidemiology: Principles and Methods. 1st ed. Iowa State University Press, Ames.

Melendez, P., G. Gonzalez, E. Aguilar, O. Loera, C. Risco, and L. F. Archbald. 2006. Comparison of two estrus-synchronization protocols and timed artificial insemination in dairy cattle. J. Dairy Sci. 89:4567-4572.

Moreira, F., R. Flores, and J. Boucher. 2004a. Use of CIDR with a timed insemination protocol in lactating dairy cows during summer in Mexico. J. Dairy Sci. 87(Suppl. 1):373. (Abstr.)

Moreira, F., R. Flores, J. Boucher, and J. Chenault. 2004b. Effects of CIDR inserts on first service pregnancy rates of lactating dairy cows submitted to a presynch program and on re-resynchronization of second service in Mexico. J. Dairy Sci. 87(Suppl. 1):256. (Abstr.)

Morrow, D. A., S. J. Roberts, K. McEntee, and H. G. Gray. 1966. Postpartum ovarian activity and uterine involution in dairy cattle. J. Am. Vet. Med. Assoc. 149:1596-1608.

Nebel, R. L., and S. M. Jobst. 1998. Evaluation of systematic breeding programs for lactating dairy cows: A review. J. Dairy Sci. 81:1169-1174.

Portaluppi, M. A., and J. S. Stevenson. 2005. Pregnancy rates in lactating dairy cows after presynchronization of estrous cycles and variations of the Ovsynch protocol. J. Dairy Sci. 88:914-921.

Pursley, J. R., R. W. Silcox, and M. C. Wiltbank. 1998. Effect of time of artificial insemination on pregnancy rates, calving rates, pregnancy loss, and gender ratio after synchronization of ovulation in lactating dairy cows. J. Dairy Sci. 81:2139-2144.

Rasmussen, F. E., M. C. Wiltbank, J. O. Christensen, and R. R. Grummer. 1996. Effects of fenprostalene and estradiol-17- $\beta$-ben- 
zoate on parturition and retained placenta in dairy cows and heifers. J. Dairy Sci. 79:227-234.

Rathbone, M. J., C. R. Bunt, C. R. Ogle, S. Burggraaf, K. L. Macmillan, C. R. Burke, and K. L. Pickering. 2002. Reengineering of a commercially available bovine intravaginal insert (CIDR insert) containing progesterone. J. Control. Release 85:105-115.

Sangsritavong, S., D. K. Combs, R. Sartori, L. E. Armentano, and M. C. Wiltbank. 2002. High feed intake increases liver blood flow and metabolism of progesterone and estradiol- $17 \beta$ in dairy cattle. J. Dairy Sci. 85:2831-2842.

Sartori, R., J. M. Haughian, R. D. Shaver, G. J. Rosa, and M. C. Wiltbank. 2004. Comparison of ovarian function and circulating steroids in estrous cycles of Holstein heifers and lactating cows. J. Dairy Sci. 87:905-920.

Sartori, R., G. J. M. Rosa, and M. C. Wiltbank. 2002. Ovarian structures and circulating steroids in heifers and lactating cows in summer and lactating and dry cows in winter. J. Dairy Sci. 85:2813-2822.

Silva, E., R. A. Sterry, and P. M. Fricke. 2007. Assessment of a practical method for identifying anovulatory dairy cows synchronized for first postpartum timed artificial insemination. J. Dairy Sci. 90:3255-3262.

Skaggs, C. L., B. V. Able, and J. S. Stevenson. 1986. Pulsatile or continuous infusion of luteinizing hormone-releasing hormone and hormonal concentrations in prepubertal beef heifers. J. Anim. Sci. 62:1034-1048.

Stevenson, J. S. 2001. A review of oestrous behaviour and detection in dairy cows. Pages 43-62 in Fertility in the High Producing Dairy Cow. Vol. 1. Occasional Pub. No. 26. Brit. Soc. Anim. Sci., Edinburgh, UK.

Stevenson, J. S., J. R. Pursley, H. A. Garverick, P. M. Fricke, D. J. Kesler, J. S. Ottobre, and M. C. Wiltbank. 2006. Treatment of cycling and noncycling lactating dairy cows with progesterone during Ovsynch. J. Dairy Sci. 89:2567-2578.

Thatcher, W. W., T. R. Bilby, J. A. Bartolome, F. Silvestre, C. R. Staples, and J. E. P. Santos. 2006. Strategies for improving fertility in the modern dairy cow. Theriogenology 65:30-44.

Washburn, S. P., W. J. Silvia, C. H. Brown, B. T. McDaniel, and A. J. McAllister. 2002. Trends in reproductive performance in southeastern Holstein and Jersey DHI herds. J. Dairy Sci. 85:244-251.

Wiltbank, M. C., H. Lopez, R. Sartori, S. Sangsritavong, and A. G̈men. 2006. Changes in reproductive physiology of lactating dairy cows due to elevated steroid metabolism. Theriogenology 65:17-29.

Wolfenson, D., G. Inbar, Z. Roth, M. Kaim, A. Bloch, and R. BrawTal. 2004. Follicular dynamics and concentrations of steroids and gonadotropins in lactating cows and nulliparous heifers. Theriogenology 62:1042-1055. 